\title{
JERZY STARNAWSKI (27 II 1922-9 XI 2012)
}

\author{
JULIAN MAŚLANKA*
}

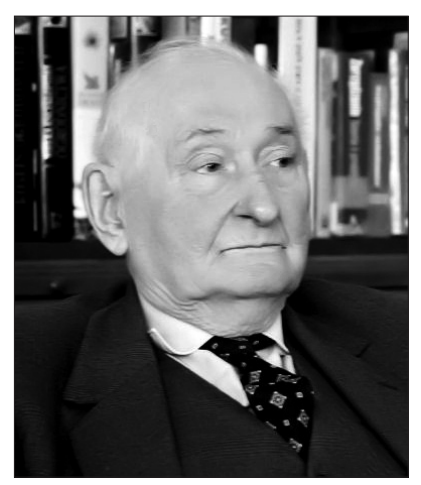

Urodził się w Guzówce (pow. Krasnystaw), gdzie jego ojciec, Tadeusz (1881-1942), do $1931 \mathrm{r}$. dzierżawił majątek w Ordynacji Zamojskiej. Matka, Maria z Kuczyńskich (zm. w 1990, w 93 roku życia), działaczka katolicka, starannie wychowywała trzech synów (była spora biblioteka domowa), z których najmłodszy „zmarł po operacji ślepej kiszki” w 1930, w wieku 5 lat i ta śmierć „złamała życie ojca oraz przyczyniła się do wielu dalszych nieszczęść"1.

Od 1931 r. rodzina Starnawskich mieszkała w Lublinie, gdzie Jerzy uczęszczał do Gimnazjum i Liceum im. Stefana Batorego i tam zdał maturę w 1939. W połowie sierpnia powołany został do Junackiego Hufca Pracy, a następnie wcielony do podchorążych rezerwy piechoty przy 19. dywizji, w której w pamiętnym dniu 17 września („,nóż w plecy” ze strony Sowietów) brał udział w obronie Grodna. Tydzień później znalazł się wśród internowanych na Litwie, ale zanim nastąpiła wywózka w głąb Rosji, udało mu się zbiec z obozu i zamieszkać przez rok (1940/41) w Wilnie. Po wybuchu wojny niemiecko-sowieckiej usiłował przedostać się do Lublina, lecz został zatrzymany przez Niemców i więziony razem z sowieckimi jeńcami - kolejno w obozach Witzendorf, Zeven oraz Sandbostel. Przeżył prawie dwa lata w skrajnie ciężkich warunkach (z tego dwa miesiące pod gołym niebem!); z zimna i głodu zmarło wielu więźniów. Dopiero w 1943 udało mu się dołączyć do jeńców polskich i wiosną 1944 uzyskać „Heimatsendung”, co umożliwiło powrót do Lublina ostatnim możliwym transportem w kwietniu 1944. Nie zastał ojca, który zmarł w 1942, o czym syn wcześniej nie mógł wiedzieć, gdyż nie miał żadnego kontaktu z rodziną.

Pod koniec okupacji niemieckiej działał w konspiracji, w tajnym nauczaniu oraz redagował pismo „W Ogniu Walki” (które następnie zmieniło tytuł na „Je-

\footnotetext{
* Julian Maślanka - prof. dr hab., prof. em. UJ.

1 J. S tar naw s ki, Autobiografia naukowa, „Analecta”, R. XII: 2003, z. 1-2 (druk 2004).
} 
stem Polakiem”). W latach ,ubeckich”, jak pisze w autobiografii, był przesłuchiwany, ale uniknął aresztowania. W 1944 r. udało się wznowić działalność KUL-u, mimo sprzeciwu kierownika oświaty PKWN Stanisława Skrzeszewskiego (późniejszego ministra), który nalegał na upaństwowienie tej uczelni. Starnawski podjął tam studia polonistyczne, a jego głównym mistrzem był wykładający wtedy (do 1948) w KUL prof. Juliusz Kleiner. Magisterium uzyskał w 1948 na podstawie rozprawy Tragizm w dziełach Karola Huberta Rostworowskiego. Podczas studiów pracował zarobkowo w Lublinie, najpierw w Bibliotece Publicznej im. Łopacińskiego, następnie jako praktykant-nauczyciel łaciny w Państwowym Gimnazjum i Liceum im. Staszica, później zaś jako nauczyciel języka polskiego w Państwowym Gimnazjum i Liceum im. J. Zamoyskiego. Już od 1956 działał w Towarzystwie Literackim im. A. Mickiewicza, a od 1959 w Polskim Towarzystwie Filologicznym. W r. 1948/49 kontynuował studia w UJ, gdzie znów słuchał wykładów Kleinera, z filozofii prof. Romana Ingardena, z wychowania estetycznego znanego psychologa Stefana Szumana, z filologii klasycznej prof. Ryszarda Gansińca i innych. Równocześnie uczył w liceum w Charsznicy koło Miechowa. W roku następnym (1949/50) studiował w UW, łącząc naukę z pracą w liceum w Legionowie, a następnie w Liceum im. M. Skłodowskiej-Curie w Warszawie. W grudniu 1949 doktoryzował się na KUL na podstawie rozprawy Słowacki- epistolograf (promotor J. Kleiner, a po jego przeniesieniu się do Krakowa, prof. S. Kawyn). W 1951 poślubił Teresę Jaruzelską, polonistkę. W 1950 zaczął pracę na KUL jako starszy asystent; w 1956 został adiunktem, w 1957 zastępcą profesora (był wtedy taki stopień, zastąpiony później przez starszego wykładowcę), a w 1958 docentem. W 1964 r. przeniósł się na Uniwersytet Łódzki, gdzie pracował do emerytury (1992). Mimo dużego i stale rosnącego dorobku naukowego, nominacje na kolejne stopnie naukowe były zapewne celowo opóźniane, gdyż profesorem nadzwyczajnym został w 1974, zwyczajnym w 1981 i w tymże roku objął kierownictwo Katedry Literatury Staropolskiej oraz Nauk Pomocniczych. W 1. 1975-1984 prowadził dodatkowo wykłady w WSP w Częstochowie. W 1992 został członkiem korespondentem, a w 1997 członkiem czynnym odrodzonej Polskiej Akademii Umiejętności. Do swego grona przyjęło go wcześniej Towarzystwo Naukowe KUL, Lubelskie Towarzystwo Naukowe, Łódzkie Towarzystwo Naukowe, Towarzystwo Przyjaciół Nauk w Przemyślu i Zamościu oraz Towarzystwo im. Marii Konopnickiej. Był wielokrotnie nagradzany oraz odznaczony Krzyżem Oficerskim Orderu Odrodzenia Polski.

Prof. Starnawski należał do najwybitniejszych polskich uczonych humanistów w II połowie XX i na początku XXI wieku. Miał szerokie zainteresowania naukowe, obejmujące różne dziedziny naszej kultury i nauki, a zwłaszcza historię literatury, dzieje nauki o polskiej literaturze, biografistykę, edytorstwo nauko- 
we (w teorii oraz praktyce), bibliografię oraz neolatynistykę, a nawet po trosze literaturę antyczną, zwłaszcza grecką. Był więc prof. Starnawski jakby ,jednoosobową instytucją naukową". Bibliografia jego publikacji jest ogromna, w tym zaś liczba tylko książek, o różnej objętości, mniejszych i większych (nie licząc wznowień), wynosi 47 (w tym 2 z udziałem autorskim jego uczniów). A niewiele mniej ma innych pozycji książkowych, bardzo ważnych, jak: edycje łacińskich tekstów autorów polskich w jego przekładzie oraz opracowaniu, wydania dzieł polskich humanistów (W. Bruchnalskiego i St. Łempickiego) z monograficznymi wstępami i komentarzami, Słownik badaczy literatury polskiej w 10 tomach pod jego redakcją i w ponad 50 procentach jego autorstwa.

Wśród pierwszej z wymienionych grup książek są dzieła o charakterze monograficznym, jak: O „Zwierzyńcu” Mikołaja Reja z Nagłowic (Wrocław 1971), Andrzej Frycz Modrzewski. Żywot, dzieło, sława (Łódź 1981), opasły tom Dzieje wiedzy o literaturze polskiej. Do końca wieku XVIII (Wrocław 1984), oparty wyłącznie na źródłowych materiałach archiwalnych Zarys dziejów Katedry Języków i Literatur Słowiańskich w Uniwersytecie Fryburskim (Wrocław 1984), Bronisław Chlebowski (Warszawa 1986) i in. Książka wydana w serii Biblioteki Polonistyki, przeznaczonej w zasadzie dla studentów i nauczycieli, pt. Średniowiecze (Warszawa 1975; wyd. 2: 1989) zawiera obszerne studium syntetyczno-monograficzne Kultura średniowiecza oraz (jak zawsze w tej serii) Materiały, czyli wybór tekstów autorów polskich i obcych o tej epoce. Syntezą zaś podręcznikową jest Zarys dziejów literatury staropolskiej (Warszawa 1993).

Był zatem prof. Starnawski - jak widać - głównie badaczem i wybitnym znawcą literatury i kultury staropolskiej. Ale nie od razu przyjął taki kierunek badań. Wspomniałem wyżej o jego rozprawie doktorskiej, poświęconej epistolografii Słowackiego, której nie wydał w całości. Jego zaś debiutem książkowym była inna praca o tym poecie, pt. Juliusz Słowacki we wspomnieniach wspótczesnych (Wrocław 1956). Kilka lat później opracował obszerną (867 s.) „antologię poetycką" pt. Adam Mickiewicz w poezji polskiej i obcej 1818-1885-1955 (Wrocław 1961). Romantyzm był mu wtedy bliski. Także w późniejszych latach powracał do twórczości wielkich romantyków.

Od nich zaczął naukową twórczość historycznoliteracką i na nich też, jakby symbolicznie, zakończył. W trzy tygodnie po odejściu z tego świata ukazały się jego dwie nowe książki (korektę robił w czasie choroby), z których jedna nosi tytuł W kręgu czterech wielkich romantyków (Łódź 2012, s. 257), gdzie we wstępie Od autora pisze:

Gdy rozpoczynałem drogę naukową, pociągał mnie przede wszystkim romantyzm. Doktoryzowałem się ze Słowackiego i temu poecie poświęciłem pierwszą moją książkę. Względy organizacyjne w strukturze polonistyki Katolickiego Uniwersytetu Lubelskiego, w którym wówczas wykładałem, sprawiły, że musiałem przerzucić się do staropolszczyzny. I zasmakowałem w niej. Od czasu do czasu wypowiadałem się na temat naszych największych poetów, którzy zawsze byli 
mi bliscy. Rozproszone studia ogłaszane w różnym czasie złożyły się na tom $W$ świecie olbrzymów. Studia o twórczości i recepcji czterech wielkich romantyków (Przemyśl 1998).

Ale kiedy odszedł z Katolickiego Uniwersytetu Lubelskiego prof. Juliusz Nowak-Dłużewski, który miał tam wykłady oraz seminaria z literatury staropolskiej, i trzeba było tę lukę wypełnić, zadanie to przypadło właśnie Starnawskiemu i „zasmakował”, jak powiada, w staropolszczyźnie. Akurat bowiem w tym czasie (1957 r.) został zastępcą profesora, a w następnym roku otrzymał stopień docenta, co upoważniało go do takiej działalności dydaktycznej. Prowadził zatem wykłady oraz seminaria z literatury staropolskiej i epoka ta, obejmująca nie tylko literaturę sensu stricto, lecz dość szeroko rozumiane piśmiennictwo (np. korespondencja ważniejszych pisarzy), tudzież niektóre wątki kultury, stały się przedmiotem intensywnych badań prof. Starnawskiego. W ogóle pomiędzy pracą dydaktyczną oraz badaniami naukowymi istniała u niego harmonijna paralela. Tak więc jako owoc ćwiczeń z nauk pomocniczych historii literatury w pierwszych latach pracy w KUL, wyrósł Warsztat bibliograficzny historyka literatury polskiej (Warszawa 1957, PWN). Był to pierwszy² u nas tego typu podręcznik uniwersytecki, wznowiony w 1971 i zmieniony w wydaniu trzecim (1983). Taki rezultat świadczy o bardzo solidnym przygotowywaniu ćwiczeń ze studentami. A jakby ciągiem dalszym tej obszernej księgi jest wydany w 1988 r., także przez warszawskie PWN Warsztat bibliograficzny historyka literatur obcych.

Po podjęciu wykładów z historii literatury staropolskiej rozwinął badania nie tylko z tego zakresu, lecz również z dziedziny trochę pokrewnej - z dziejów nauki o literaturze polskiej, czego owocem jest m.in. obszerne dzieło Dzieje wiedzy o literaturze polskiej. Do końca wieku XVIII (Wrocław 1984, Ossolineum). Narastały rozprawy i artykuły w czasopismach oraz pracach zbiorowych, które następnie zebrane pod wspólnym tytułem ukazywały się w książkach, co zwłaszcza w późniejszych latach działalności naukowej prof. Starnawskiego stanowiło częstą praktykę wydawniczą. Taki jest tom Odrodzenie. Czasy, ludzie, ksiq̨żki (Łódź 1991), który zawiera sporą porcję solidnej wiedzy o różnych sprawach mało znanych lub nieznanych z wcześniejszych publikacji, jak: ,geografia literacka" doby renesansu, pisarze ziemi przemyskiej w dawnych wiekach, związki umysłowe Warmii i Mazur z Krakowem i Małopolską w czasach Odrodzenia, czy wreszcie odsłonięcie lub dokładniejsze naświetlenie różnych szczegółów z życia i twórczości wielu pisarzy XVI wieku.

Prof. Starnawski znakomicie panował nad wszystkimi okresami literatury i także kultury staropolskiej, a swymi badaniami znacząco i systematycznie

${ }^{2}$ Później ukazało się podobne dzieło: J. Czachowska, R. Loth, Przewodnik polonisty. Bibliografie. Słowniki. Biblioteki. Muzea literackie, Wrocław 1974, wyd. 2 uzupełnione - 1981, wyd. 3 - 1989. 
wzbogacał stan wiedzy. Po wymienionych książkach o Średniowieczu i Odrodzeniu (tudzież osobnych studiach o Reju oraz Modrzewskim), do których to epok powracał później z nowymi tematami (o czym dalej wypadnie wspomnieć), przyszła kolej na zbiór rozpraw W świecie barokowym (Łódź 1992). Wykorzystał tu częściowo osobno wcześniej wydane szkice Barok w literaturze (Kraków 1973) oraz Wespazjan Kochowski (Kraków 1988), do których doszły inne prace, a zwłaszcza dwie z nich dużej wagi: Ze studiów nad Sarbiewskim oraz Ze studiów nad Szymonem Starowolskim. Pierwsza z nich odznacza się gruntownością i erudycją, szczególnie część Z dziejów sławy Macieja Kazimierza Sarbiewskiego, w której omówione zostały „,wydania”, ,przekłady na języki obce”, „,reminiscencje i nawiązania” autorów obcych do naszego poety, „głosy o Sarbiewskim z dawnych wieków”, do których dołączył później wielki muzyk, Robert Schumann, jako ,głosiciel sławy i tłumacz Sarbiewskiego”.

Natomiast Starowolski należał do prozaików łacińskich, których Starnawski tłumaczył na język polski i komentował. W tym przypadku chodzi o dwa duże dzieła: Setnik pisarzów polskich [...] (Kraków 1970) oraz Wojownicy sarmaccy [...] (Warszawa 1979). W książce o baroku zamieścił dwie rozprawy: „Hekatontas, czyli Setnik pisarzów” i poczq̨tki bibliografii polskiej oraz $O$ „Wojownikach sarmackich”.

Kontynuując informacje o pracach odnoszących się do piśmiennictwa staropolskiego, wypadnie odnotować, iż w tym samym roku, kiedy ukazał się zbiór W świecie barokowym, czyli w 1992, wyszła też książka popularnonaukowa Średniowieczna poezja religijna (w serii Biblioteka Analiz Literackich), a w roku następnym praca Drogi rozwojowe hagiografii polskiej i łacińskiej w wiekach średnich (w: Pontificia Acadenia Theologica Cracoviensis - jako vol. 5).

Nowe zaś artykuły czy szkice „staropolskie”, jakie ciągle pojawiały się w wielu czasopismach jak również w innych publikacjach, umożliwiały kompletowanie nowych zbiorów. Należy do nich tom Wieki średnie i wiek renesansowy. Studia (Łódź 1996), zawierający kilkanaście szkiców, ułożonych w czterech grupach: Zagadnienia ogólne kultury i literatury średniowiecznej; Z badań nad gatunkami literackimi w najdawniejszych wiekach; W kręgu poezji religijnej; Wśród pisarzy wieku złotego.

W 2007 r. ukazały się dwa tomy. Tom pierwszy pt. Z dziejów renesansu w Polsce. Studia i szkice (w ramach „Studiów staropolskich. Series nova” IBL, z udziałem również PAU) zawierający m.in. szkice o młodzieńczych poezjach łacińskich Hozjusza, o Kromerze, Modrzewskim, Reju, Kochanowskim, Górnickim i innych. Tom zaś drugi (ponad 600 str.), pt. Pisarze jezuiccy w Polsce (wiek XVI do XIX). Studia i materiały (Kraków, WAM), grupuje teksty (po części znane z wcześniejszych książek Starnawskiego) w czterech częściach. W pierwszej o przekładzie Biblii przez Wujka oraz O Skardze; w drugiej o Sarbiewskim; trzecia ma tytuł Z badań nad komentarzem Adama Naruszewicza do Tacyta „Dzieł wszystkich” (1772-1783); wreszcie część czwarta odnosi się do paru pisarzy 
Akademii Połockiej. Natomiast kilka lat wcześniej wydany został obszerny tom (560 s.) pt. Polska w Europie (Kraków 2001, Collegium Columbinum), wykraczający poza staropolszczyznę i sięgający aż do wieku XX, zawierający ponad 30 szkiców w czterech działach chronologicznych: Od zarania dziejów do końca panowania Jagiellonów; $W$ czasach $d w u$ pierwszych królów elekcyjnych; Od M. K. Sarbiewskiego do upadku Polski; Z wieków XIX i XX. Prace tutaj zamieszczone traktują o ludziach czy zjawiskach z kultury polskiej, które odegrały jakąś znaczniejszą rolę w skali europejskiej; nie tylko o postaciach tak wybitnych jak np. Sarbiewski czy Jan Dantyszek, ale też mniej znanych lub nawet dziś zapomnianych. I vice versa, czyli chodzi $\mathrm{m}$. in. o kontakty naukowe wybitnych obcokrajowców - takie, jakie miał np. Filip Melanchton z Polakami.

Jerzy Starnawski jako badacz literatury często „wkraczał” (nb. lubił używać tego określenia, gdy pisał o literaturoznawcach) w epoki bliższe naszych czasów niż staropolszczyzna, m. in. w końcowych tekstach wspomnianej książki Polska w Europie, czy w kolejnym tomie pt. Od zarania dziejów literatury polskiej po wiek XX (Łódź 2003). W tym tomie, złożonym z przedruków 23 szkiców (jak zwykle gruntownie przerobionych), przedostatnim jest Tragizm $w$,Judaszu z Kariothu” Rostworowskiego (zamieszczony jeszcze w 1951 r. w „Przeglądzie Powszechnym" i stanowiący jego debiut naukowy), a ostatnim (z 1983 r.) tekst $O$ „Tryptyku ewangelicznym” Leopolda Staffa.

Wskazano wyżej, że karierę uniwersytecką, dydaktyczną i naukową zaczął od romantyzmu, w szczególności od Słowackiego i Mickiewicza. Otóż jego zamiłowanie do naszych największych poetów nigdy nie osłabło, powracał do nich, a po latach ukazał się tom $W$ świecie olbrzymów. Studia o twórczości i recepcji czterech wielkich romantyków (Przemyśl 1998), w którym jest 26 tekstów, drukowanych wcześniej (z wyjątkiem jednego) od roku 1956 do 1998. Wśród nich jeden po francusku, bardzo interesujący: Le thème du „double” dans l'oeuvre dramatique de Zygmunt Krasiński et de Juliusz. Słowacki, zamieszczony w księdze zbiorowej pt. Double et dédoublement en littérature (Lyon 1995). Chodzi, oczywiście, o pary bohaterów powiązanych ze sobą np. wspólnotą ideałów, albo też przeciwstawnych sobie wzajemnie. Starnawski przytacza tu wiele przykładów z literatury polskiej, jak np. w Konradzie Wallenrodzie Konrad i Halban, w Anhellim bohater tytułowy i Szaman, w Nie-boskiej komedii hrabia Henryk i Pankracy. Problem ten ukazał komparatystycznie, odwołując się też do wielu przykładów z literatur zachodnioeuropejskich. Nb. prof. Starnawski parokrotnie ogłaszał swe prace po francusku i ten język był mu bodaj najlepiej znany (oprócz łaciny), bowiem zaczął się go uczyć najwcześniej - od matki (jak powiedział kiedyś piszącemu te słowa).

Po wydaniu książki o czterech romantykach (Mickiewicz, Słowacki, Krasiński i Norwid) narosły o nich nowe studia, jakie zawiera wspomniany już tom, który ukazał się z początkiem grudnia 2012, jakby symboliczne zamknięcie bogatego dorobku naukowego Autora. Nosi tytuł W kręgu czterech wielkich roman- 
tyków (Łódź 2012), przy czym niemal połowa tekstów poświęcona tu została Słowackiemu, w tym sporych rozmiarów studium syntetyczne Juliusz Słowackipoeta, którego pierwodruk zamieszczony został w 10-tomowej Historii literatury polskiej (t. 5, cz. 2, Bochnia 2003). Nic więc dziwnego, że jako autor tego oraz wielu innych studiów o Słowackim, podjął się napisania wstępu i kompetentnego opracowania drugiego wydania czterotomowej monografii Juliusz Słowacki. Dzieje twórczości (Kraków 2003), dzieła swego Mistrza, Juliusza Kleinera.

Po pierwszej książce o romantykach przyszła kolej na zbiór szkiców o niektórych problemach dotyczących twórczości głównych prozaików pozytywizmu i Młodej Polski, ale też pisarzy z innych okresów. Taki zbiór pt. Reymont i inni (Warszawa 2002), skompletowany został z okazji Roku Reymontowskiego (2000). W dwóch pierwszych rozprawach poddane zostały analizie dwa reportaże Reymonta - Pielgrzymka do Jasnej Góry i Z ziemi chełmskiej, w którym pisarz ukazał męczeństwo unitów, zwłaszcza z Pratulina, w naszych czasach beatyfikowanych (6 X 1996) przez Jana Pawła II. Obie prace wyposażone zostały w bogatą obudowę erudycyjną na temat ukazywanych przez Reymonta faktów. To samo zaś można powiedzieć o kolejnym szkicu pt. Żeromski - Reymont. Próba paraleli.

Ponadto są prace o zasygnalizowanych w tytule książki „,innych”, czyli o pisarstwie Jędrzeja Kitowicza, o Kraszewskim, szczególnie zaś o jego powieści Kordecki (1850), o Dziurdziach Orzeszkowej, listach Prusa, badaczach Sienkiewicza (J. Kleiner i Z. Szweykowski), wreszcie o twórczości Zofii Kossak-Szczuckiej oraz dramatach K. H. Rostworowskiego.

Poza zasadniczą problematyką historycznoliteracką, o jakiej była wyżej mowa, Jerzy Starnawski podejmował też różne tematy, niejako „drugoplanowe”, głównie w ostatnim piętnastoleciu działalności, a więc w okresie emerytalnym. Okazuje się jednak, że są one wcale istotne i obejmują znaczną część jego dorobku naukowego. Do najważniejszych należą dwie dziedziny: dzieje nauki o literaturze polskiej oraz biografistyka obejmująca humanistów, a zwłaszcza historyków naszej literatury. Całość rezultatów owej, zamkniętej już działalności naukowej, podzielić można na trzy zespoły. Do pierwszego należą książki mające częściowo charakter syntetycznych ujęć dziejów nauki o literaturze polskiej w określonym okresie, po części zaś traktują o pewnych szczegółowych kwestiach badawczych u poszczególnych uczonych, albo wreszcie ukazują ich życiorysy. Drugi zespół obejmuje książki zawierające „sylwetki historyków literatury”, a trzeci stanowi „czysta” biografistyka, czyli Słownik badaczy literatury polskiej.

Do pierwszego zespołu należą 4 książki niemalże o takich samych tytułach: $Z$ dziejów polskiej nauki o literaturze w wieku XIX i XX. Cztery studia (Częstochowa 1997), Z dziejów polskiej nauki o literaturze. Dwanaście rozpraw (Łowicz 
2004), Z dziejów polskiej nauki o literaturze. Seria III. Dwanaście rozpraw (Łódź 2007) i Z dziejów polskiej nauki o literaturze. Seria IV. Piętnaście rozpraw (Łódź 2011). Pierwodruki tych „rozpraw” były, oczywiście, nieco wcześniejsze. Pierwsza z owych książek ma najbardziej syntetyczny charakter. Przedstawia najpierw dzieje nauczania literatury w uczelniach polskich (Kraków, Wilno, Warszawa, Lwów i Krzemieniec) w pierwszych trzech dziesięcioleciach XIX wieku (do powstania listopadowego). Druga rozprawa $O$ uniwersyteckim nauczaniu literatury polskiej w latach 1830-1862 dotyczy Lwowa i Krakowa. Trzecia pt. Pokolenie wielkich humanistów polskich, ukazuje licznych uczonych, nie tylko historyków literatury, działających w ostatnim dwudziestoleciu XIX wieku i w okresie międzywojennym. Wreszcie czwarta przedstawia rozwój historycznoliterackiej monografistyki polskiej, od pierwocin w I połowie XIX w. do roku 1995.

Natomiast trzy kolejne książki różnią się dość znacznie od pierwszej. W drugiej (2004 r.) oprócz wstępnego eseju (zresztą interesującego) O godności i znaczeniu pracowników naukowych, tylko dwie kolejne rozprawy nawiązują swym syntetycznym ujęciem do tomu poprzedniego. Chodzi o rozprawę $O$ nauczaniu uniwersyteckim historii literatury polskiej w ostatnich dziesiqtkach lat XIX wieku (nie tylko w dwóch uniwersytetach galicyjskich, lecz też po trosze w Europie Zachodniej) i znacznie obszerniejszą pt. Zarys dziejów katedr historii literatury polskiej w Uniwersytecie Lwowskim. Rozdziały zaś dalsze traktują o historykach literatury polskiej, jak np. szkic Stanisław Pigoń - Juliusz Kleiner (Paralela), Konrad Górski jako syntetyk dziejów literatury polskiej itp. Podobną konstrukcję mają też tomy oznaczone jako seria III i IV.

W pierwszym z nich są na początku dwie rozprawy: Krytyka literacka $i$ polska nauka o literaturze w dobie Młodej Polski oraz Nauka o literaturze w latach 1918-1939. W serii zaś IV szkice wstępne mają charakter inny, bardziej ogólnych rozważań. Ich tytuły wskazują na przedmiot owych rozważań: Historia literatury a historia kultury oraz Literatura słowiańska czy literatury słowiańskie. A następnie w serii III są takie szkice, jak np. Aleksander Brückner - wielki inspirator, Ignacy Chrzanowski wobec Norwida, Wacław Borowy jako badacz literatury staropolskiej i oświeceniowej, Maria Dłuska i jej szkoła wersyfikacyjna itp. Natomiast w serii IV po początkowych szkicach znajdują się biogramy badaczy literatury z różnych okresów od Sylwetek krzemienieckich historyków literatury (M. Jurkowski, A. Osiński, E. Słowacki, A. Feliński T. Sierociński i J. Korzeniowski) poczynając, po czym następuje ,przeskok” do Młodej Polski (I. Matuszewski), okresu międzywojennego (St. Kot, St. Łempicki i inni) i do współczesności (E. Jankowski, J. Rudnicka, Z. Kopczyńska, L. Pszczołowska, M. Jasińska-Wojtkowska, D. Zamącińska-Paluchowska, a z żyjących M. Bokszczanin - z okazji przyznania jej nagrody Pen Clubu Polskiego).

Wspomniany drugi zespół tejże tematyki stanowią trzy tomy o historykach literatury trzech ośrodków uniwersyteckich. Są to Sylwetki wileńskich historyków literatury (Bydgoszcz 1997), gdzie mowa o historykach nie tylko literatu- 
ry polskiej, począwszy od takich postaci, jak F. N. Golański, G. E. Groddeck, L. Borowski, a skończywszy na M. Kridlu i K. Górskim. Analogiczny tom, czyli Sylwetki lwowskich historyków literatury (Łódź 1997), zawiera ,szkice biograficzne" (termin Autora) takich uczonych, jak A. Małecki, R. Piłat, E. Porębowicz, W. Bruchnalski i inni aż do Kleinera, St. Łempickiego i Wł. Tarnawskiego. Kilka lat później ukazał się tom Sylwetki lubelskich humanistów XIX i pierwszej połowy XX wieku (Lublin 2004), który zaczyna się od biogramów pięciu postaci z okresu zanim powstał (w 1918) Katolicki Uniwersytet Lubelski (najbardziej znany i zasłużony z nich to Hieronim Łopaciński). Późniejsi zaś humaniści, związani z KUL, uszeregowani zostali w dwóch grupach: działający w okresie międzywojennym (15 sylwetek) oraz po drugiej wojnie światowej (12 osób), przy czym Autor uwzględnia też takich profesorów, którzy przejściowo pracowali w KUL, jak np. Stefan Srebrny czy Tadeusz Milewski.

Tak silne zamiłowanie do biografistyki ukierunkowanej na humanistów, zwłaszcza historyków literatury polskiej, prowadziło wprost do stworzenia dzieła dość niezwykłego, jakie normalnie tworzyć powinien zespół przynajmniej kilkuosobowy, zatrudniony na płatnych etatach. Prof. Starnawski zaś sam zainicjował, redagował i wydawał od 1994 r. (nakładem Łódzkiego Towarzystwa Naukowego) Słownik badaczy literatury polskiej (bo właśnie o to dzieło chodzi), stosując tzw. ,system holenderski” (czyli każdy tom zawiera biogramy od A do Z, w miarę ich kompletowania). Miał wprawdzie pewną ilość współpracowników, głównie spośród znajomych polonistów, ale sam był autorem większości haseł. Do 2009 r. ukazało się dziesięć tomów! Do nich dodany został w osobnych dwóch broszurach indeks, znakomicie ułatwiający orientację w całości dzieła.

W tak bardzo rozbudowanej biografistyce prof. Starnawski osobne miejsce zarezerwował dla „ludzi książki”. Taki bowiem tytuł mają dwa odrębne tomy; pierwszy wydany w 2000 r. w Częstochowie, drugi osiem lat później w Lublinie. Konstrukcja obydwu jest podobna, tzn. ich zawartość dzieli się na dwie części, gdzie w pierwszej są - by tak rzec ogólnie - szkice z historii bibliofilstwa, a część druga obejmuje, jak to zatytułował Autor w tomie z 2000 r., Konterfekty ludzi ksiażki XIX i XX wieku, a w tomie z 2008 r. tak samo, tylko chronologia odnosi się do XX i XXI wieku. Takich „konterfektów” jest 12 w książce pierwszej i 7 w drugiej, dotyczą zaś ludzi przeważnie osobiście znanych Autorowi, jak np. (w t. I) Piotr Grzegorczyk, Zofia Ciechanowska, Józef Mayer, czy jedyny z nich dziś żyjący, były dyrektor Biblioteki KUL, bardzo zasłużony dla swej instytucji, zarazem przyjaciel prof. Starnawskiego, Andrzej Paluchowski. Osoby zaś, których biogramy weszły do drugiej książki, bodaj wszystkie Autor znał osobiście, co najmniej ze spotkań kongresowych. Należą do nich Stefan Vrtel-Wierczyński, Helena Hleb-Koszańska, Jadwiga Rudnicka, Maria Danilewicz-Zielińska i inne.

Natomiast teksty zamieszczone w częściach pierwszych obydwu książek są ciekawymi przyczynkami bibliofilskimi o mało znanych lub nieznanych sprawach. Z braku miejsca wystarczy jeden przykład; w szkicu Rajmunda Brzozow- 
skiego „Słownik pisarzów polskich” w części odnaleziony (t. z 2000 r.) chodzi o rękopis Słownika autorstwa ostatniego rektora (w 1. 1817-1820) jezuickiej Akademii Połockiej, o którym wiadomo było, że istniał i zaginął. Tymczasem pierwszy z pięciu tomów (obejmujący nazwiska na litery A-E) odnalazł się w Bibliotece Watykańskiej, co jest jednym z licznych odkryć prof. Starnawskiego.

Kolejną dziedziną humanistyki, a zwłaszcza filologii polskiej, w której prof. Starnawski był wybitnym i twórczym specjalistą, jest naukowe edytorstwo dzieł literackich. Dał tego dowód w różnych pracach, a szczególnie w książce Praca wydawcy naukowego (Wrocław 1979, wyd. 2 poszerzone 1992), wydanej w ossolińskiej serii Książki o Książce. Wcześniej główne w nauce polskiej dzieło na ten temat napisał Konrad Górski pt. Sztuka edytorska. Zarys teorii (Warszawa 1956, wyd. 2, w nowej wersji inny tytuł: Tekstologia i edytorstwo dzieł literackich, Warszawa 1975), ale książka Starnawskiego, owszem, znacznie skromniejsza niż Górskiego (co zresztą sam Autor podkreśla we wstępie), okazała się bardzo użyteczna, głównie dla studentów polonistyki i pracowników poważnych wydawnictw naukowych. Nowością w stosunku do dzieła Górskiego jest dodana przy końcu książki Kronika edytorstwa naukowego w Polsce, licząca w drugiej edycji 50 stron.

Wreszcie, jak już wyżej zaznaczono, prof. Starnawski był wybitnym neolatynistą, co tym ważniejsze, że neolatynistyka polska jest dziś jakby w zaniku i cierpi na chroniczny deficyt specjalistów. Jest ich w Polsce może kilku, więc tym samym wielka część naszego dawnego piśmiennictwa w języku łacińskim nie znajduje badaczy. O swej zaś pracy w tej dziedzinie prof. Starnawski tak mówi we wspomnianej już Autobiografii naukowej:

Domeną moją jako badacza literatury staropolskiej stała się od 1957 r. neolatynistyka. [...] Marzyłem o zagranicznych studiach, co nie było mi dane, ale na kongresy międzynarodowe, zwłaszcza neolatynistyczne, udało mi się wyjeżdżać. Uczestniczyłem w jedenastu kongresach neolatynistycznych i w trzech latynistycznych-mediewistycznych. A bywałem i na kongresach poświęconych retoryce, na latynistycznych, na których trzeba było wygłaszać referaty nie w języku niemieckim lub francuskim, ale łacińskim (s. 298).

Więcej na ten temat pisze w książce Kongresy, sympozja, sesje naukowe (Częstochowa 1999), zresztą nie tylko o wyżej wymienionych (na s. 42-163), lecz także innych, w jakich brał udział. Chcąc zaś rozbudzić na szerszą skalę tego typu badania, w 1978 r. stworzył w UŁ Podyplomowe Studium Neolatynistyczne, ,przeznaczone dla młodych pracowników naukowych oraz doktorantów ze wszystkich dziedzin humanistycznych z całej Polski”. Studium to dobrze funkcjonowało przez 10 lat, do 1987 r., do czasu, kiedy prof. Starnawski doznał zawału serca (drugiego z kolei). Dodać tu wypadnie, że wcześniej neolatynistyczne 
zajęcia (poza normalnymi obowiązkami uniwersyteckimi) prowadził przez kilka lat prof. Tadeusz Ulewicz w UJ. Przyjeżdżali na nie co kilka tygodni na 5-6 godzin młodzi pracownicy naukowi też z całej Polski, m. in. asystenci z Łodzi. Ale Ulewicz prowadził owo studium sam, natomiast Starnawski (zresztą bliski przyjaciel Ulewicza) zorganizował zespół wykładowców, do którego (prócz niego) wchodził prof. Stefan Zabłocki z Gdańska, prof. Juliusz Domański z Warszawy i kilka innych osób.

Nawet z tak pobieżnego przeglądu dorobku naukowego Starnawskiego widać, że współpracował on z licznymi środowiskami intelektualnymi w Polsce, a także za granicą. Szczególne zaś więzy łączyły Go (oprócz Łodzi, gdzie najdłużej pracował) z Lublinem i Lubelszczyzną oraz z Przemyślem i Zamościem. I tym właśnie miastom poświęcił dwie książki. Pierwsza z nich nosi tytuł Między Wisła i Bugiem. Lublin - Zamość - Chełm - Nałęczów (Lublin 2010), gdzie we wstępie Od autora czytamy:

Syn Ziemi Lubelskiej, urodzony w Guzówce (gm. Wysokie, par. Turobin, pow. Krasnystaw, dziś Biłgoraj), mieszkający od blisko czterech dziesiątków lat poza granicami województwa, pragnie wypłacić się u schyłku życia temu regionowi [...].

Z czterech szkiców o Lublinie warto choćby wymienić np. Życie naukowe Lublina w latach 1918-1939 oraz zwrócić uwagę na ważny tekst Lublin i Ziemia Lubelska w oczach okupanta (1939-1944), gdzie Autor obficie cytuje artykuły dotyczące „dystryktu” lubelskiego z wydawanego w Krakowie miesięcznika (od października 1940 do czerwca 1944) „Das General-Gouvernement”. Przebija z nich nienasycona żarłoczność w stylu „Drang nach Osten” i bezczelnie kłamliwa propaganda germańska, według której Lublin, Zamość i inne miasta są „urdeutschen”, a Lubelszczyzna uznana za „Nebenland” i „Vorposten im Osten des Großdeutschen Reiches”, przeznaczona głównie „nur für Deutsche”.

Natomiast w grudniu 2012, równocześnie z książką o czterech wielkich romantykach (o czym wyżej), ukazała się też druga pt. Z ziemi przemyskiej i krain sqsiednich, gdzie zebrane zostały wcześniej drukowane różne teksty, głównie litteraria - czyli o pisarzach (A. Krzycki, M. Kromer, M. Bielski, St. Orzechowski, W. Goślicki i inni), którzy mieli jakieś powiązania z Przemyślem lub Ziemią Przemyską.

Do ukochanego Lublina powrócił Jerzy po śmierci. Tam bowiem 17 listopada (sobota) odbyły się uroczystości pogrzebowe w kościele akademickim KUL i na starym cmentarzu przy ul. Lipowej, gdzie spoczął w grobie rodzinnym, żegnany przez żonę Teresę, córkę Marię oraz liczną rzeszę przyjaciół i znajomych.

\section{POSTSCRIPTUM}

Piszącego te słowa łączyło z prof. Jerzym Starnawskim ponad 40 lat znajomości i niewiele mniej lat przyjaźni. Ostatnia telefoniczna rozmowa między nami 
odbyła się 9 listopada 2012 tuż po godz. 20. On zatelefonował (jak zwykle o tej porze) i słabym głosem zapytał, jak wypadły wybory do zarządu Wydziału Filologicznego PAU (w tym właśnie dniu się odbyły). A w drugim zdaniu powiedział, że ,jeszcze nie otrzymał PAUzy” (internetowy tygodnik PAU), w której drukowano Jego artykuł (w 5 odcinkach). Ja przekazałem tę Jego wcześniejszą prośbę do redakcji, żeby wysyłano po kolei każdy numer; niestety, nie uczyniono tego i potem tłumaczono mi, że planowano wysłać razem wszystkie numery. W trzecim zdaniu Jurek powiedział, że jest „bardzo słaby”. Ja na to: „Kochany, trzymaj się”, a on: „Dziękuję, dziękuję”. I tyle. Następnego dnia rano, ok. godz. 7.30, otrzymałem wiadomość, że Jerzy zmarł poprzedniego dnia wieczorem, a więc około 20-30 minut po naszej rozmowie. Tego nie można zapomnieć! 